\title{
Hirsutane Sesquiterpenes from Cultures of the Basidiomycete Marasmiellus sp. BCC 22389
}

\author{
Masahiko Isaka · Somporn Palasarn • \\ Malipan Sappan · Sumalee Supothina • \\ Thitiya Boonpratuang
}

Received: 26 July 2016/Accepted: 18 August 2016/Published online: 26 August 2016

(C) The Author(s) 2016. This article is published with open access at Springerlink.com

\begin{abstract}
Two new hirsutane sesquiterpenes, marasmiellins A (1) and B (2), were isolated from cultures of the basidiomycete Marasmiellus sp. BCC 22389. The structures were elucidated on the basis of NMR spectroscopic and mass spectrometry data. The absolute configuration of marasmiellin B was determined by application of the modified Mosher's method.
\end{abstract}

Graphical Abstract

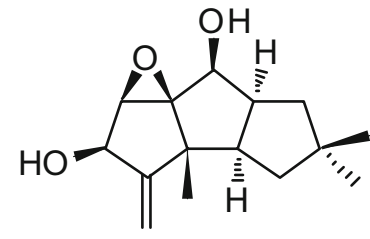

marasmiellin A (1)

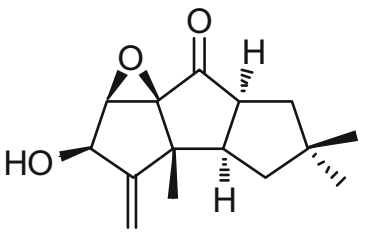

marasmiellin B (2)

Keywords Marasmiellus · Basidiomycete · Hirsutane sesquiterpenoid

\section{Introduction}

Mushrooms have been valued as potent sources of bioactive compounds $[1,2]$. While some medicinal species have been well investigated, many species remain chemically unexplored or poorly studied. Marasmiellus is a relatively

Electronic supplementary material The online version of this article (doi:10.1007/s13659-016-0105-7) contains supplementary material, which is available to authorized users.

M. Isaka $(\varangle) \cdot$ S. Palasarn · M. Sappan · S. Supothina .

T. Boonpratuang

National Center for Genetic Engineering and Biotechnology

(BIOTEC), 113 Thailand Science Park, Phaholyothin Road,

KlongLuang, Pathumthani 12120, Thailand

e-mail: isaka@biotec.or.th large genus composed of more than 400 described species/subspecies; however, there have been only a few reports on the chemical constituents from this genus: ciscaryophillane sesquiterpenes from fermentation broth of Marasmiellus troyanus [3], picolinic acid derivatives (CJ14,877 and CJ-14,897; cytokine production inhibitors) from Marasmiellus sp. CL21624 [4], and benzoxepine derivatives from $M$. ramealis $[5,6]$. As part of our research program on utilization of fungal sources in Thailand, bioassay and chemical profile-based screenings were performed in an effort to discover novel bioactive compounds with diverse chemical structures. In particular, we have recently been focusing on basidiomycetes as diverse sources of bioactive terpenoids [7-9]. Reported herein are the results of the chemical investigation of Marasmiellus 
sp. BCC 22389. Although an extract from cell cultures from this fungus were inactive in a panel of biological assays, it displayed a unique and complex ${ }^{1} \mathrm{H}$ NMR profile, demonstrating the occurrence of terpenoids. Scale-up fermentation and chemical studies of BCC 22389 led to the isolation and characterization of two new hirsutane-type sesquiterpenes, marasmiellins A (1) and B (2) (Fig. 1).

\section{Results and Discussion}

The molecular formula of marasmiellin A (1) was determined by HRESIMS as $\mathrm{C}_{15} \mathrm{H}_{22} \mathrm{O}_{3}$. The ${ }^{13} \mathrm{C}$ NMR, DEPT135 and HMQC spectroscopic data indicated the presence of 15 carbons categorized as an exomethylene group $\left(\delta_{\mathrm{C}} 160.4, \mathrm{qC} ; \delta_{\mathrm{C}} 112.0, \mathrm{CH}_{2}\right)$, an oxygenated quaternary carbon $\left(\delta_{\mathrm{C}} 77.3\right)$, three oxymethines $\left(\delta_{\mathrm{C}} 74.2,70.7\right.$ and 63.8), two $s p^{3}$ quaternary carbons, two methine, two

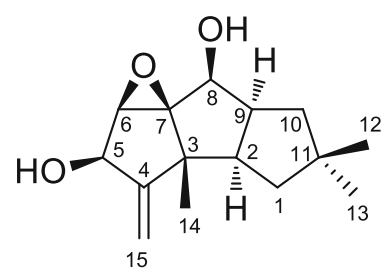

1

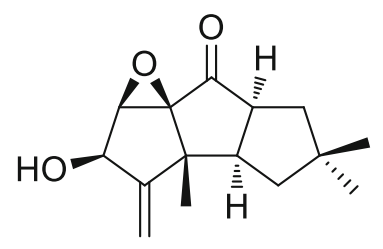

2 methylene, and three methyl groups (Table 1). The planar structure was deduced from ${ }^{1} \mathrm{H}-{ }^{1} \mathrm{H}$ COSY and HMBC data to be a typical hirsutane sesquiterpene. The COSY data indicated the linkage of C-1-C-2-C-9-C-10 and connection of an oxymethine $\left(\mathrm{C}-8, \delta_{\mathrm{C}} 70.7 ; \mathrm{H}-8, \delta_{\mathrm{H}} 4.02\right)$ to $\mathrm{C}-9$. The presence of geminal dimethyl groups $\left(\mathrm{CH}_{3}-12\right.$ and $\mathrm{CH}_{3}-13$ ) was revealed by the HMBC correlations of these methyl protons to the other methyl carbon to each other ( $\mathrm{H}_{3}-12$ to $\mathrm{C}-13$, and $\mathrm{H}_{3}-13$ to $\mathrm{C}-12$ ), and the correlations from both methyl protons $\left(\mathrm{H}_{3}-12\right.$ and $\left.\mathrm{H}_{3}-13\right)$ to attached quaternary carbon $(\mathrm{C}-11)$ and two methylene carbons $(\mathrm{C}-1$ and $\mathrm{C}-10$ ). These data revealed the presence of a fivemembered ring composed of $\mathrm{C}-1, \mathrm{C}-2, \mathrm{C}-9, \mathrm{C}-10$, and $\mathrm{C}-11$. HMBC correlations from $\mathrm{H}-1\left(\delta_{\mathrm{H}} 1.50\right), \mathrm{H}-2$, and $\mathrm{H}-9$ to a quaternary carbon at $\delta_{\mathrm{C}} 48.6$ (C-3) indicated the $\mathrm{C}-2-\mathrm{C}-3$ bond. Methyl protons at $\delta_{\mathrm{H}} 1.22\left(\mathrm{H}_{3}-14\right)$ showed intense HMBC correlations to C-2, C-3, an exomethylene quaternary carbon (C-4), and an oxygenated quaternary carbon (C-7), which demonstrated the attachment of $\mathrm{CH}_{3}-$ 14 to $\mathrm{C}-3$. HMBC correlations from $\mathrm{H}-8$ to $\mathrm{C}-9, \mathrm{C}-2, \mathrm{C}-3$, $\mathrm{C}-7$, and an oxygenated methine carbon $\left(\delta_{\mathrm{C}} 63.8\right.$, C-6) revealed the $\mathrm{C}-7-\mathrm{C}-8$ bond to form the central five-membered ring (C-2, C-3, C-7, C-8, and C-9), and connection of C-6 to C-7. COSY correlation of H-6 with another oxymethine proton at $\delta_{\mathrm{H}} 4.61(\mathrm{H}-5)$, and HMBC correlations from exomethylene protons $\left(\mathrm{H}_{2}-15\right)$ to $\mathrm{C}-3, \mathrm{C}-4$, and $\mathrm{C}-5$ requested the terminal five-membered ring structure (C-3, C-4, C-5, C-6, C-7). Finally, presence of an epoxide

Fig. 1 Structures of marasmiellins A (1) and B (2)

Table 1 NMR spectroscopic data for 1 and $2\left(\mathrm{CDCl}_{3}, 400 \mathrm{MHz}\right.$ for ${ }^{1} \mathrm{H}$ NMR, $100 \mathrm{MHz}$ for ${ }^{13} \mathrm{C}$ NMR $)$

\begin{tabular}{|c|c|c|c|c|c|c|}
\hline \multirow[t]{2}{*}{ Position } & \multicolumn{3}{|c|}{ Marasmiellin A (1) } & \multicolumn{3}{|c|}{ Marasmiellin B (2) } \\
\hline & $\delta_{\mathrm{C}}$, multi & $\delta_{\mathrm{H}}$, multi $(J$ in $\mathrm{Hz})$ & HMBC & $\delta_{\mathrm{C}}$, multi & $\delta_{\mathrm{H}}$, multi $(J$ in $\mathrm{Hz})$ & HMBC \\
\hline 1 & $40.5, \mathrm{CH}_{2}$ & $\alpha 1.45, \mathrm{~m} ; \beta 1.50, \mathrm{~m}$ & $2,3,9,10,11,13$ & $40.3, \mathrm{CH}_{2}$ & $\alpha 1.68, \mathrm{~m} ; \beta 1.70, \mathrm{~m}$ & $2,3,10$ \\
\hline 2 & $49.3, \mathrm{CH}$ & $2.31, \mathrm{~m}$ & $1,3,4,9$ & $44.7, \mathrm{CH}$ & $2.65, \mathrm{~m}$ & $1,3,4,10,12$ \\
\hline 3 & 48.6, qC & & & 47.7, qC & & \\
\hline 4 & $160.4, \mathrm{qC}$ & & & $158.1, \mathrm{qC}$ & & \\
\hline 5 & $74.2, \mathrm{CH}$ & 4.61, br d $(8.4)$ & & $74.4, \mathrm{CH}$ & 4.76, br d (8.8) & 4 \\
\hline $5-\mathrm{OH}$ & & 1.76 , br d (8.4) & & & 1.79, br d $(8.8)$ & \\
\hline 6 & $63.8, \mathrm{CH}$ & $3.57, \mathrm{~d}(2.0)$ & 4,5 & $65.5, \mathrm{CH}$ & $3.83, \mathrm{~d}(1.9)$ & $4,5,8$ \\
\hline 7 & $77.3, \mathrm{qC}$ & & & 75.0, qC & & \\
\hline 8 & $70.7, \mathrm{CH}$ & $4.02, \mathrm{~d}(6.7)$ & $2,3,6,7$ & $210.0, \mathrm{qC}$ & & \\
\hline 9 & $45.7, \mathrm{CH}$ & $2.84, \mathrm{~m}$ & $1,2,3,10$ & $50.5, \mathrm{CH}$ & 3.09, ddd $(12.0,11.1,8.6)$ & $3,8,10$ \\
\hline 10 & $38.9, \mathrm{CH}_{2}$ & $\begin{array}{l}\alpha 1.38, \mathrm{~m} \\
\beta 1.74, \mathrm{t}(11.7)\end{array}$ & $\begin{array}{l}1,2,11,13 \\
8,9,11,12,13\end{array}$ & $42.8, \mathrm{CH}_{2}$ & $\begin{array}{l}\alpha 1.83, \mathrm{dd}(12.4,8.6) \\
\beta 1.74, \mathrm{dd}(12.4,12.0)\end{array}$ & $\begin{array}{l}1,2,13 \\
8,9,11\end{array}$ \\
\hline 11 & $41.9, \mathrm{qC}$ & & & $42.3, \mathrm{qC}$ & & \\
\hline 12 & $29.2, \mathrm{CH}_{3}$ & $1.14, \mathrm{~s}$ & $1,10,11,13$ & $28.6, \mathrm{CH}_{3}$ & $1.15, \mathrm{~s}$ & $1,10,11,13$ \\
\hline 13 & 27.6, $\mathrm{CH}_{2}$ & $0.94, \mathrm{~s}$ & $1,10,11,12$ & $28.2, \mathrm{CH}_{3}$ & $0.96, \mathrm{~s}$ & $1,10,11,12$ \\
\hline 14 & $18.8, \mathrm{CH}_{3}$ & $1.22, \mathrm{~s}$ & $2,3,4,7$ & $18.6, \mathrm{CH}_{3}$ & $1.14, \mathrm{~s}$ & $2,3,4,7$ \\
\hline 15 & 112.0, $\mathrm{CH}_{2}$ & $5.27, \mathrm{~d}(2.1) ; 5.03, \mathrm{~d}(2.1)$ & $3,4,5$ & 113.7, $\mathrm{CH}_{2}$ & $5.39, \mathrm{~d}(2.1) ; 5.14, \mathrm{~d}(2.1)$ & $3,4,5$ \\
\hline
\end{tabular}




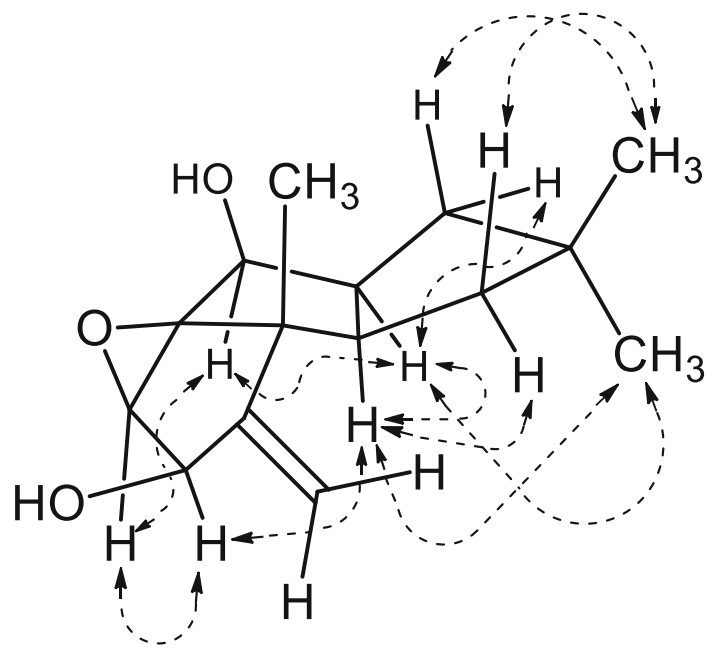

Fig. 2 Key NOESY correlations for $\mathbf{1}$

was a requirement from the molecular formula (HRMS). The location of the epoxide was assigned to be C-6/C-7 on the basis of the chemical shifts of $\mathrm{H}-5, \mathrm{C}-5$, and C- 6 , therefore, a hirsutane skeleton was established for $\mathbf{1}$. The relative configuration of $\mathbf{1}$ was determined on the basis of the NOESY correlations (Fig. 2). The round NOESY correlation network of $\mathrm{H}-5 / \mathrm{H}-6, \mathrm{H}-6 / \mathrm{H}-8, \mathrm{H}-8 / \mathrm{H}-9$, and $\mathrm{H}-9 /$ $\mathrm{H}-2$ indicated that all these protons oriented on the same side $(\alpha)$ of the tricyclic ring, and these data also requested the cis/cis ring junctions and $\beta$-orientation of the epoxide and $\mathrm{CH}_{3}-14$. The assignments of protons for $\mathrm{H}_{\alpha}-1 / \mathrm{H}_{\beta}-1$, $\mathrm{H}_{\alpha}-10 / \mathrm{H}_{\beta}-10$, and $\mathrm{H}_{3}-12 / \mathrm{H}_{3}-13$ were also established on the basis of the NOESY correlations.

The molecular formula of marasmiellin $\mathrm{B}$ (2) was determined by HRESIMS as $\mathrm{C}_{15} \mathrm{H}_{20} \mathrm{O}_{3}$. The ${ }^{1} \mathrm{H}$ and ${ }^{13} \mathrm{C}$ NMR spectroscopic data were similar to those of $\mathbf{1}$. A remarkable difference was the presence of a ketone $\left(\delta_{\mathrm{C}}\right.$ $210.0)$ replacing the oxymethine $(\mathrm{C}-8)$ in $\mathbf{1}$. HMBC correlations from $\mathrm{H}-9$ and $\mathrm{H}_{\alpha}-10\left(\delta_{\mathrm{H}} 1.83\right)$ to the ketone carbon indicated the location. Detailed analyses of the NOESY spectrum confirmed that its relative configuration was identical to $\mathbf{1}$. Consequently, marasmiellin B (2) was identified as the C-8 ketone variant of $\mathbf{1}$. The absolute configuration of $\mathbf{2}$ was determined by application of the modified Mosher's method [10]. The $\Delta \delta$ values of the $(S)$ and $(R)$-MTPA esters $\mathbf{3 a}$ and $\mathbf{3 b}$, respectively, indicated the $5 R$ configuration (Fig. 3).

Marasmiellins are hirstane-type sesquiterpenes structurally close related to coriolins [11]. Although this class of secondary metabolites are common in basidiomycetes, this is the first report of the isolation from Marasmiellus genus. Compounds 1 and $\mathbf{2}$ were inactive in the cytotoxicity assays against cancer cell-lines (KB, MCF-7, and NCIH187) [12] at a concentration of $50 \mu \mathrm{g} / \mathrm{mL}$. They were also inactive in assays for antitubercular (Mycobacterium

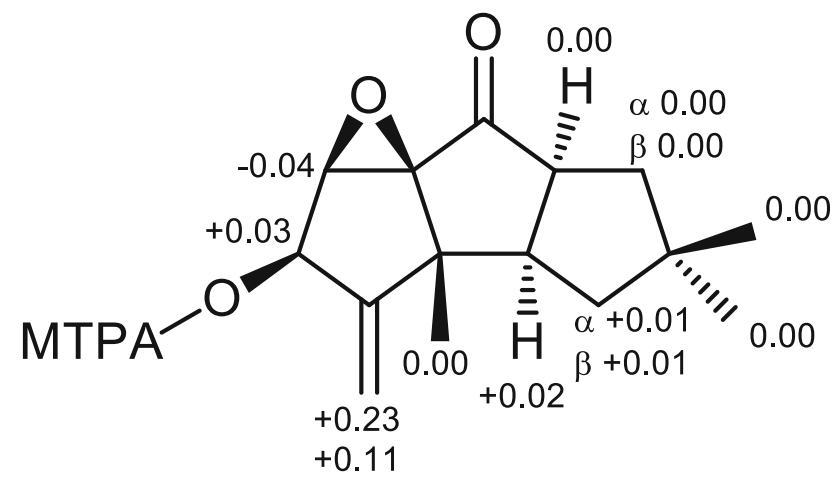

3a (S)-MTPA ester

3b (R)-MTPA ester

Fig. $3 \Delta \delta$-Values $\left(\delta_{S}-\delta_{R}\right)$ of the Mosher esters 3a and $\mathbf{3 b}$

tuberculosis $\mathrm{H} 37 \mathrm{Ra}$ ) and antimalarial (Plasmodium falciparum $\mathrm{K} 1$ ) activities.

\section{Experimental}

\subsection{General Experimental Procedures}

Melting points were measured with an Electrothermal IA9100 digital melting point apparatus. Optical rotations were measured with a JASCO P-1030 digital polarimeter. UV spectra were recorded on an Analytik Jena SPEKOL 1200 spectrophotometer. IR spectra were taken on a Bruker ALPHA spectrometer. NMR spectra were recorded on a Bruker DRX400 spectrometer. ESITOF mass spectra were measured with a Bruker micrOTOF mass spectrometer.

\subsection{Fungal Material}

The fungus used in this study was collected on an unidentified decayed twig in Sakarat Research Unit, Chachoengsao province, Thailand. The natural mushroom specimen was deposited in the BIOTEC Bangkok Herbarium as BBH 16982. The living culture was deposited in the BIOTEC Culture Collection on July 27, 2006, as BCC 22389. On the basis of the morphology of the mushroom specimen and the ITS rDNA sequence data (GenBank accession number: KT800055) this fungus was identified as the genus Marasmiellus of the family Marasmiaceae, but it was not assignable to the species level.

\subsection{Fermentation, Extraction, and Isolation}

The fungus BCC 22389 was fermented in a $1000 \mathrm{~mL}$ Erlenmeyer flask containing $250 \mathrm{~mL}$ of malt extract broth (MEB; malt extract $6.0 \mathrm{~g} / \mathrm{L}$, yeast extract $1.2 \mathrm{~g} / \mathrm{L}$, maltose 
$1.8 \mathrm{~g} / \mathrm{L}$, dextrose $6.0 \mathrm{~g} / \mathrm{L}$ ) at $25^{\circ} \mathrm{C}$ for 38 days under static conditions. The cultures were filtered to separate broth and mycelia (residue). The broth was extracted with EtOAc $(3 \times 50 \mathrm{~mL})$ and concentrated under reduced pressure to obtain a brown gum (broth extract, $34 \mathrm{mg}$ ). The wet mycelia were macerated in $\mathrm{MeOH}(200 \mathrm{~mL}, \mathrm{rt}, 2$ days $)$ and filtered. Hexanes $(150 \mathrm{~mL})$ and $\mathrm{H}_{2} \mathrm{O}(50 \mathrm{~mL})$ were added to the filtrate, and the layers were separated. The $\mathrm{H}_{2} \mathrm{O}$ / $\mathrm{MeOH}$ (bottom) layer was partially concentrated by evaporation, and the residue was extracted with EtOAc $(200 \mathrm{~mL})$. The EtOAc layer was concentrated under reduced pressure to obtain a brown gum (mycelial extract, $26 \mathrm{mg}$ ). The broth extract was passed through a column on Sephadex LH-20 $(2.8 \times 50 \mathrm{~cm})$ and eluted with $\mathrm{MeOH}$ to obtain three pooled fractions. Fraction $2(21 \mathrm{mg})$ was subjected to column chromatography (CC) on silica gel $\left(1.8 \times 15 \mathrm{~cm}, \mathrm{MeOH} / \mathrm{CH}_{2} \mathrm{Cl}_{2}\right.$, step gradient elution from 0:100 to 20:80) to furnish $2(4.1 \mathrm{mg})$ and $\mathbf{1}(4.0 \mathrm{mg})$. The mycelial extract was also fractionated using the similar chromatographic protocols to give $2(1.5 \mathrm{mg})$ and $\mathbf{1}$ $(1.1 \mathrm{mg})$.

Marasmiellin A (1): colorless solid; mp $140-141^{\circ} \mathrm{C}$; $[\alpha]_{\mathrm{D}}^{26}+53(c 0.12, \mathrm{MeOH}) ; \mathrm{UV}(\mathrm{MeOH}) \lambda_{\max }(\log \varepsilon): 210$ (3.21) nm; IR (ATR) $v_{\max } 3218,2952,1742,1071,1058$, 924, $774 \mathrm{~cm}^{-1}$; for ${ }^{1} \mathrm{H}$ NMR (400 MHz, $\mathrm{CDCl}_{3}$ ) and ${ }^{13} \mathrm{C}$ NMR (100 MHz, $\mathrm{CDCl}_{3}$ ) data, see Table 1; HRESIMS: $\mathrm{m} /$ z. 273.1466 (calcd for $\mathrm{C}_{15} \mathrm{H}_{22} \mathrm{O}_{3} \mathrm{Na}[\mathrm{M}+\mathrm{Na}]^{+}, 273.1461$ ).

Marasmiellin B (2): colorless solid; $\mathrm{mp} 122-123^{\circ} \mathrm{C}$; $[\alpha]_{\mathrm{D}}^{26}+43(c 0.09, \mathrm{MeOH}) ; \mathrm{UV}(\mathrm{MeOH}) \lambda_{\max }(\log \varepsilon): 215$ (3.32) nm; IR (ATR) $v_{\max } 3407,2952,1088,940$, $773 \mathrm{~cm}^{-1}$; for ${ }^{1} \mathrm{H}$ NMR $\left(400 \mathrm{MHz}, \mathrm{CDCl}_{3}\right.$ ) and ${ }^{13} \mathrm{C} \mathrm{NMR}$ $\left(100 \mathrm{MHz}, \mathrm{CDCl}_{3}\right)$ data, see Table 1; HRESIMS $\mathrm{m} /$ $z 271.1306$ (calcd for $\mathrm{C}_{15} \mathrm{H}_{20} \mathrm{O}_{3} \mathrm{Na}[\mathrm{M}+\mathrm{Na}]^{+}, 271.1305$ ).

\subsection{Synthesis of Mosher Esters 3a and $\mathbf{3 b}$}

Compound $2(0.5 \mathrm{mg})$ was treated with $(-)-(R)-\mathrm{MTPA}-\mathrm{Cl}$ $(15 \mu \mathrm{L})$ in pyridine $(0.2 \mathrm{~mL})$ at room temperature for $16 \mathrm{~h}$. The mixture was diluted with EtOAc and washed with $\mathrm{H}_{2} \mathrm{O}$ and $1 \mathrm{M} \mathrm{NaHCO}$. The organic layer was dried over anhydrous $\mathrm{MgSO}_{4}$ and concentrated in vacuo to give a mixture containing a $(S)$-MTPA ester derivative $3 \mathbf{a}:{ }^{1} \mathrm{H}$ NMR $\left(400 \mathrm{MHz}, \mathrm{CDCl}_{3}\right) \delta 7.57-7.41(5 \mathrm{H}, \mathrm{m}$, phenyl of MTPA), $5.90\left(1 \mathrm{H}\right.$, br s, H-5), $5.24\left(1 \mathrm{H}, \mathrm{s}, \mathrm{H}_{\mathrm{a}}-15\right), 5.18(1 \mathrm{H}$, $\left.\mathrm{s}, \mathrm{H}_{\mathrm{b}}-15\right), 4.05(1 \mathrm{H}, \mathrm{s}, \mathrm{H}-6), 3.55\left(3 \mathrm{H}, \mathrm{br} \mathrm{s},-\mathrm{OCH}_{3}\right.$ of MTPA), $3.14(1 \mathrm{H}, \mathrm{m}, \mathrm{H}-9), 2.76(1 \mathrm{H}, \mathrm{m}, \mathrm{H}-2), 1.85(1 \mathrm{H}$, $\left.\mathrm{m}, \mathrm{H}_{\alpha}-10\right), 1.73\left(1 \mathrm{H}, \mathrm{m}, \mathrm{H}_{\beta}-1\right), 1.70\left(1 \mathrm{H}, \mathrm{m}, \mathrm{H}_{\alpha}-1\right), 1.45$ $\left(1 \mathrm{H}, \mathrm{t}, J=12.1 \mathrm{~Hz}, \mathrm{H}_{\beta}-10\right), 1.15(6 \mathrm{H}, \mathrm{s}, \mathrm{H}-12$ and $\mathrm{H}-14)$,
0.98 (3H, s, H-13). Similarly, (R)-MTPA ester derivative 3b was prepared from 2 and $(+)-(S)$-MTPA-Cl: ${ }^{1} \mathrm{H}$ NMR (400 MHz, $\left.\mathrm{CDCl}_{3}\right) \delta 7.58-7.40(5 \mathrm{H}, \mathrm{m}$, phenyl of MTPA), $5.87(1 \mathrm{H}, \mathrm{s}, \mathrm{H}-5), 5.09\left(1 \mathrm{H}, \mathrm{s}, \mathrm{H}_{\mathrm{a}}-15\right), 5.01\left(1 \mathrm{H}, \mathrm{s}, \mathrm{H}_{\mathrm{b}}-15\right)$, $4.09(1 \mathrm{H}, \mathrm{s}, \mathrm{H}-6), 3.59\left(3 \mathrm{H}, \mathrm{br} \mathrm{s},-\mathrm{OCH}_{3}\right.$ of MTPA), 3.14 $(1 \mathrm{H}, \mathrm{m}, \mathrm{H}-9), 2.74(1 \mathrm{H}, \mathrm{m}, \mathrm{H}-2), 1.85(1 \mathrm{H}, \mathrm{dd}, J=12.7$, $\left.8.1 \mathrm{~Hz}, \mathrm{H}_{\alpha}-10\right), 1.72\left(1 \mathrm{H}, \mathrm{m}, \mathrm{H}_{\beta^{-}}-1\right), 1.71\left(1 \mathrm{H}, \mathrm{m}, \mathrm{H}_{\alpha^{-}}-1\right)$, $1.45\left(1 \mathrm{H}, \mathrm{t}, J=12.4 \mathrm{~Hz}, \mathrm{H}_{\beta}-10\right), 1.15(6 \mathrm{H}, \mathrm{s}, \mathrm{H}-12$ and H-14), 0.98 (3H, s, H-13).

Acknowledgments Financial support from the National Science and Technology Development Agency (Grant No. P-13-00856) is gratefully acknowledged.

\section{Complianace with Ethical Standards}

Conflict of Interest The authors declare no conflicts of interest.

Open Access This article is distributed under the terms of the Creative Commons Attribution 4.0 International License (http:// creativecommons.org/licenses/by/4.0/), which permits unrestricted use, distribution, and reproduction in any medium, provided you give appropriate credit to the original author(s) and the source, provide a link to the Creative Commons license, and indicate if changes were made.

\section{References}

1. D.D. De Silva, S. Rapior, E. Sudarman, M. Stadler, J. Xu, S.A. Alias, K.D. Hyde, Fungal Divers. 62, 1-40 (2013)

2. M.J. Alves, I.C.F.R. Ferreira, D.J.V. Teixeira, A. Martins, M. Pintado, M. Planta Med. 78, 1707-1718 (2012)

3. L. Evans, J. Hedger, G. O'Donnell, B.W. Skelton, A.H. White, R.T. Williamson, S. Gibons, Tetrahedron Lett. 51, 5493-5496 (2010)

4. K. Ichikawa, H. Hirai, M. Ishiguro, T. Kambara, Y. Kato, Y.J. Kim, Y. Kojima, Y. Matsunaga, H. Nishida, Y. Shiomi, N. Yoshikawa, N. Kojima, J. Antibiot. 54, 73-79 (2001)

5. J.K. Holroyde, A.F. Orr, V. Thaller, J. Chem. Soc. Chem. Comm. 242-243 (1976)

6. M.Y. Jarrah, V. Thaller, J. Chem. Soc. Perkin Trans. 1, 1719-1721 (1983)

7. M. Isaka, P. Chinthanom, S. Kongthong, K. Srichomthong, R. Choeyklin, Phytochemistry 87, 133-139 (2013)

8. M. Isaka, U. Srisanoh, W. Choowong, T. Boonpratuang, Org. Lett. 13, 4886-4889 (2011)

9. M. Isaka, S. Palasarn, M. Sappan, K. Srichomthong, S.C. Karunarathna, K.D. Hyde, Nat. Prod. Commun. 10, 1391-1393 (2015)

10. I. Ohtani, T. Kusumi, Y. Kashman, H. Kakisawa, J. Am. Chem. Soc. 113, 4092-4096 (1991)

11. S. Takahashi, H. Nagasawa, H. Iinuma, T. Takita, K. Maeda, H. Umezawa, Tetrahedron Lett. 12, 1955-1958 (1971)

12. J. O'Brien, I. Wilson, T. Orton, F. Pognan, Eur. J. Biochem. 267, 5421-5426 (2000) 